\title{
Two tectonically significant enclaves in the Nordre Strømfjord shear zone at Ataneq, central West Greenland
}

\author{
William E. Glassley, John A. Korstgård and Kai Sørensen
}

The Nordre Strømfjord shear zone is a $1.8 \mathrm{Ga}$ zone of largescale, transcurrent and sinistral ductile shear (Sørensen et al. 2006) within the Nagssugtoqidian Mobile Belt (NMB) of central West Greenland. It has been hypothesised that the NMB is a suture between two Archaean continental masses (Kalsbeek et al. 1987). During field work in 2005 along the Nordre Strømfjord shear zone in the fjord Ataneq (Fig. 1), some unusual rock types were discovered that preserve evidence of magmatic and metamorphic processes not previously reported in the area. These observations include the first indication of high-pressure (HP) metamorphism in West Greenland and the first reported occurrence of a cumulate of giant orthopyroxene. The tectonic telescoping of these features together within the Nordre Strømfjord shear zone has important implications for reconstructing the Palaeoproterozoic history of this region, and provides evidence that processes typical of Phanerozoic continent-continent collision zones (e.g. the Caledonian and Alpine systems) operated at least as far back as $1.8 \mathrm{Ga}$ ago.

\section{High-pressure enclave}

On the north side of inner Ataneq fjord an approximately 1.2 $\mathrm{m}$ wide and $4 \mathrm{~m}$ long lens of ultramafic rock occurs within strongly foliated garnet-sillimanite gneisses and schists, and garnet-bearing calc-silicate rock (Fig. 2). The pale yellowish green, ultramafic rock is moderately foliated with its long axis parallel to the fabric in the enclosing gneisses. This core of the

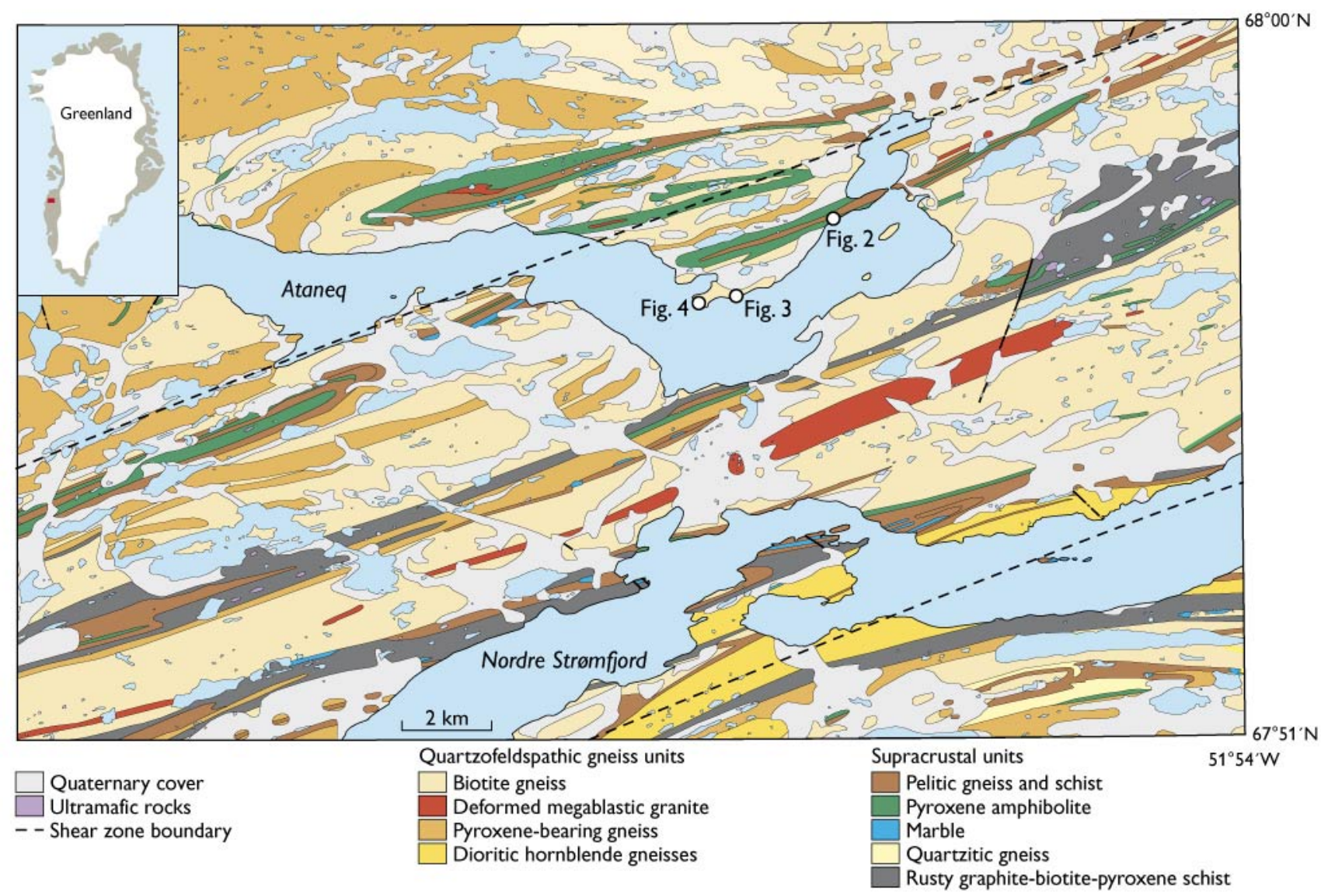

Fig. 1. North-eastern part of the Agto map sheet (Olesen 1984), with the localities of Figs 2, 3 and 4 marked. The Nordre Strømfjord shear zone of the map area is characterised by vertically oriented supracrustal units alternating with quartzofeldspathic units, as also described by Sørensen et al. (2006) from the area to the east. The regional amphibolite to granulite facies transition occurs over the eastern part of the map. 


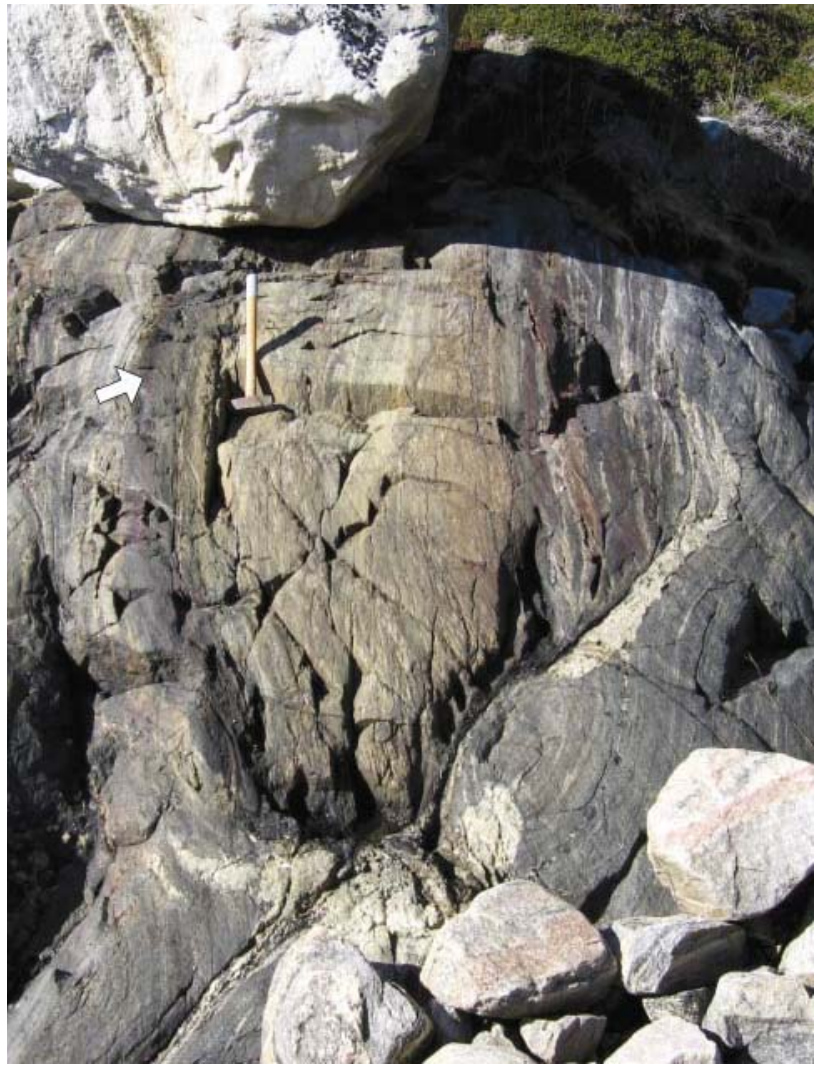

Fig. 2. Lens (boudin?) of yellowish green, ultramafic rock within garnetbiotite-sillimanite gneiss and calc-silicate rock. The hammer $(1 \mathrm{~m})$ rests on the ultramafic rock and is just to the right of a dark, $30 \mathrm{~cm}$ thick rim (indicated by arrow) that completely encloses the ultramafic lens. The dark rim is the source of the garnet-spinel-olivine-orthopyroxeneclinopyroxene sample. For location see Fig. 1.

enclave consists of anthophyllite with a few minor additional phases. It is surrounded by a dark rim of dense, fine-grained rock approximately $30 \mathrm{~cm}$ thick (Fig. 2) that is conformable to the shape of the ultramafic lens. The rim appears to be the result of a reaction between the silica-poor ultramafic rocks and the enclosing aluminium- and silica-rich metasediments, and it consists of olivine-orthopyroxene-clinopyroxene-spinelgarnet-amphibole. The fine-grained nature of the rim rock and its complex textural characteristics make it difficult to unambiguously decipher all aspects of its petrogenetic history. However, certain key observations show that the rim rock records an unusual history involving high-pressure metamorphism. The olivine occurs as remnant crystals that are occasionally seen to be in optical continuity but separated by pyroxene and spinel. Garnets occur as isotropic areas that are nearly completely overgrown by spinel and pyroxene. Garnet also occurs as inclusions in spinel. All combinations of grain-to-grain contacts have been observed, with the exception of garnet-olivine. There are also textural features suggesting that two generations of orthopyroxene and clinopyroxene may be present.

These mineralogical features document a petrogenetic history in which the oldest mineral assemblage preserved in the rim of the enclave is garnet-olivine-orthopyroxene-clinopyroxene (i.e. garnet peridotite). The occurrence of garnet + olivine in ultramafic rocks and the occurrence of eclogite minerals in mafic compositions are the diagnostic mineral assemblages for HP metamorphism. Defined in this way HP metamorphism is intermediate between granulite facies metamorphism and ultra high-pressure metamorphism (UHP) in which diamond and coesite are stable phases. In the HP enclave, the olivine + garnet-bearing assemblage is replaced, via reaction between olivine and garnet, by the assemblage spinel-orthopyroxene-clinopyroxene (i.e. spinel peridotite). Olivine and garnet are preserved because the reaction was arrested before it went to completion. This metamorphism took place at a very low thermodynamic activity of water. Replacement of a garnet peridotite mineral assemblage by that of spinel peridotite is the hallmark of recrystallisation during decompression from minimum pressures of about $18-20$ kilobars $\left(>60 \mathrm{~km}\right.$ ) and temperatures $>750^{\circ} \mathrm{C}$ (Schmädicke \& Evans 1997; Fumagalli \& Poli 2005).

Preliminary electron microprobe analyses of all of the mineral phases have been conducted. Clinopyroxene-orthopyroxene geothermometry and orthopyroxene-garnet geobarometry (Brey \& Köhler 1990) intersect at $785^{\circ} \mathrm{C}$ and $21 \mathrm{~kb}$. However, uncertainty in identifying cogenetic minerals, as well as the fact that these rocks have experienced extensive recrystallisation during decompression and cooling make it likely that these $P-T$ conditions are a minimum; modifications are to be expected as further analyses are conducted.

The electron microprobe data provide support for the argument that the high density rim around the ultramafic rock is, in fact, a metasomatic feature reflecting steep chemical potential gradients between the metasediments and the ultramafic rock. In particular, the very high modal abundance of the spinel (>20\%) and the absence of detectable Cr in any of the minerals are inconsistent with primary crystallisation from an ultramafic composition. Rather, these characteristics suggest limited metasomatic reaction between the enclave and the surrounding metasediments into which we envisage the enclave to have been tectonically emplaced.

\section{Giant orthopyroxene cumulate with inter- stitial anorthosite and associated rocks}

Approximately $3 \mathrm{~km}$ west of the HP site a series of gabbroic anorthosite and coarse-grained orthopyroxenite lenses occur that are metres to tens of metres in size (Fig. 3). This series of lenses is traceable along the coast over a distance of $1 \mathrm{~km}$. The 
Fig. 3. Two $3 \mathrm{~m}$ long lenses of gabbro anorthosite approximately $2 \mathrm{~km}$ west of the ultramafic lens shown in Fig. 2. Note the duplex structure within the lens. For location see Fig. 1.

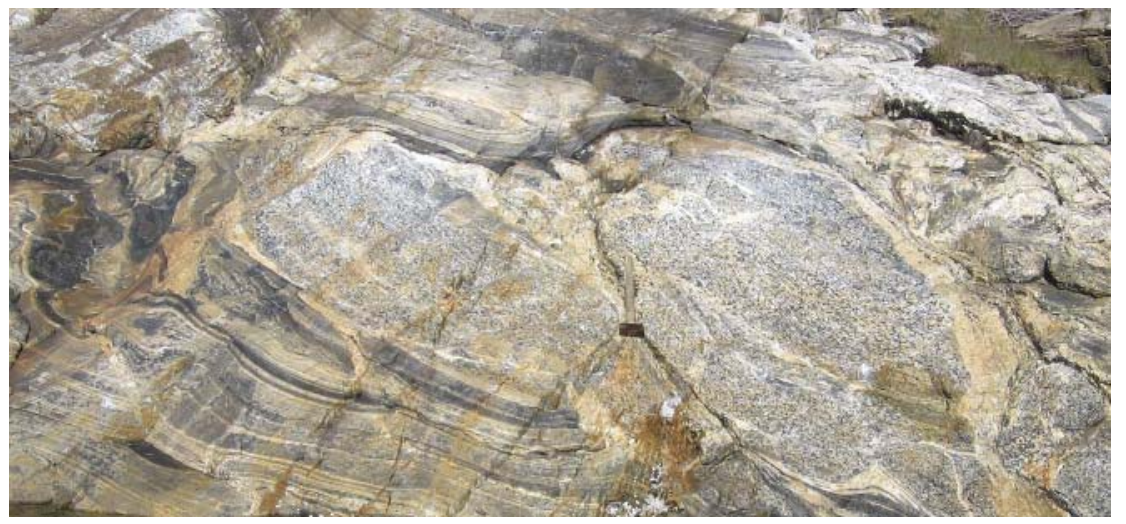

margins of these lenses are tectonised at their contact with the enclosing quartzofeldspathic gneisses.

The orthopyroxenites were observed in two distinct forms. One of these is a monomineralic lens of thumb-sized, equant, euhedral to subhedral orthopyroxene crystals. The lens is approximately two metres by four metres in size and exhibits no internal fabric. The other form is a spectacular giant orthopyroxene cumulate containing crystals more than $30 \mathrm{~cm}$ long and $15 \mathrm{~cm}$ wide that have a strong preferred orientation, with long axes parallel to each other in a classic cumulate texture. The crystals exhibit striking macroscopic kink banding (Fig. 4). Anorthosite is found as discontinuous films along the edges of the orthopyroxene crystals and as cuspate pockets where triple junctions of orthopyroxene crystals occur.

In thin section the orthopyroxenites are seen to have preserved detailed evidence of a complex magmatic history and metamorphic recrystallisation, even though field evidence unequivocally shows these rocks to have been tectonically emplaced into their present setting. The primary magmatic mineral assemblage consists of remnant forsteritic olivine incompletely resorbed by orthopyroxene, green spinel and plagioclase with chromite, rutile, phlogopite, apatite and zircon as additional phases, either primary or a result of exsolution. All of these minerals are observed as inclusions within the orthopyroxene, as well as phases interstitial to orthopyroxene in pockets of anorthosite. Secondary minerals associated with metamorphic recrystallisation are amphibole (as trains of small grains within orthopyroxene, occurring along crystallographically controlled planes) and quartz.

Reconnaissance electron microprobe analyses of the plagioclase show that its composition is affected by its environment: plagioclase grains within the anorthositic pockets are close to $\mathrm{An}_{60}$, while those contained within the orthopyroxene, which generally are associated with amphibole, are approximately $\mathrm{An}_{40}$. The amphibole is nearly pure cummingtonite. Other observations made with the electron microprobe showed the presence of $\mathrm{Fe}-\mathrm{Ni}$ sulphides and pure $\mathrm{Cu}$ spherules. In addition, the spinels and phlogopites are Tiand Cr-rich.

These characteristics of the orthopyroxenites suggest that the cumulates formed by gravitational settling of giant orthopyroxenes in a magma chamber. The presence of plagioclase, clinopyroxene and rutile exsolution lamellae suggests that the orthopyroxenes crystallised at high pressure $(>10 \mathrm{~kb})$, which is consistent with the co-existence of orthopyroxene-olivine-plagioclase-spinel.

It has been postulated that anorthositic massifs form via fractionation of orthopyroxene from magmas of appropriate compositions at or near the base of the continental crust (Emslie 1985). However, such cumulates have never been observed before, and the slivers of cumulate orthopyroxenite observed in Ataneq may be the remnants of such a system that has been tectonically dismembered

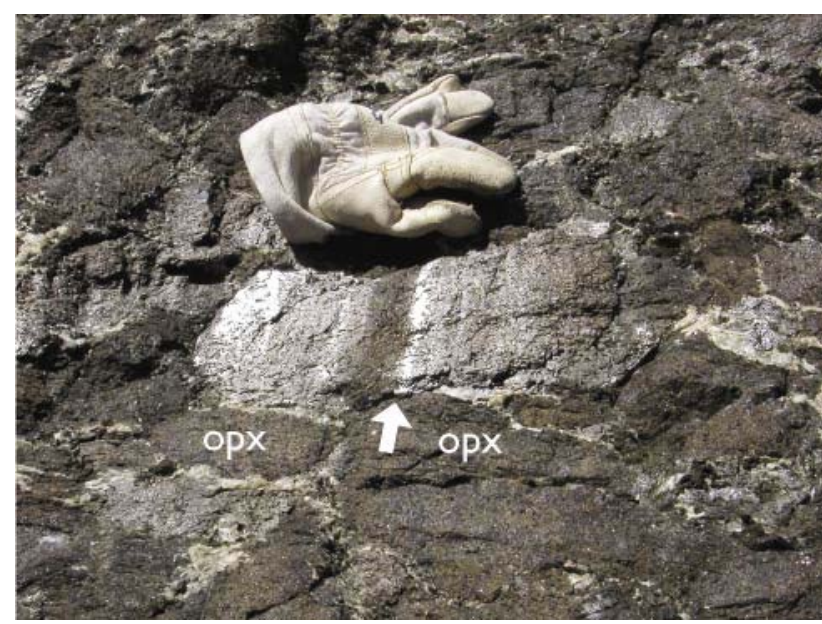

Fig. 4. Giant orthopyroxene crystals (dark olive green except where reflecting) separated by grey and white intercumulus anorthosite. Glove above the large single crystal in the centre of the photograph is approximately $20 \mathrm{~cm}$ long. Note kink banding in the central crystal (arrow points towards the kink band). opx, orthopyroxene. For location see Fig. 1. 


\section{Conclusions}

The high-pressure rocks and orthopyroxenite cumulates observed in Ataneq attest to tectonic telescoping of rocks that originated from profoundly different geological environments. They provide evidence that within the Nordre Strømfjord shear zone, samples of the deepest levels of continental crust and the upper mantle are present. These rocks occur within contrasting lithologies of the Nordre Strømfjord shear zone: the HP lens within a supracrustal unit (sensu Sørensen et al. 2006) and the pyroxenite-anorthosite assemblage within a quartzofeldspathic gneiss unit. Further to the east, a complex of lenses of ultramafic rocks, pillow lavas and unusual tourmaline-phlogopite rocks (interpreted to be the metamorphosed remnant of submarine hot-spring exhalations; Sørensen et al. 2006) have been observed enclosed in supracrustal units. These rock types provide compelling evidence that upper mantle, deep continental crust and oceanic crust were tectonically juxtaposed, probably during continent-continent collision, later to be deformed within the Nordre Strømfjord shear zone. The tectonism responsible for the emplacement of these rocks within continental rocks may be thrust stacking as described by van Gool et al. (1999) and Sørensen et al. (2006) south of the shear zone near the Inland Ice.

\section{Acknowledgement}

The work of W.E.G. was funded by the University of Aarhus.

\section{References}

Brey, G.P. \& Köhler, T. 1990: Geothermobarometry in four-phase lherzolites. II. New thermobarometers and practical assessment of existing thermobarometers. Journal of Petrology 31, 1353-1378.

Emslie, R.F. 1985: Proterozoic anorthosite massifs. In: Tobi, A.C. \& Touret, J.L.R. (eds): The deep proterozoic crust in the North Atlantic Provinces. NATO ASI Series 158, 39-60.

Fumagalli, P. \& Poli, S. 2005: Experimentally determined phase relations in hydrous peridotites to $6.5 \mathrm{Gpa}$ and their consequences on the dynamics of subduction zones. Journal of Petrology 46, 555-578.

Kalsbeek, F., Pidgeon, R.T. \& Taylor, P.N. 1987: Nagssugtoqidian mobile belt of West Greenland: a cryptic 1850 Ma suture between two Archaean continents - chemical and isotopic evidence. Earth and Planetary Science Letters $\mathbf{8 5}, 365-385$.

Olesen, N.Ø. 1984: Geological map of Greenland, 1:100 000, Agto, 67 V.1 Nord. Copenhagen: Geological Survey of Greenland.

Schmädicke, E. \& Evans, B.W. 1997: Garnet-bearing ultramafic rocks from the Erzgebirge, and their relation to other settings in the Bohemian Massif. Contributions to Mineralogy and Petrology 127, 57-74.

Sørensen, K., Korstgård, J.A., Glassley, W.E. \& Stensgaard, B.M. 2006: The Nordre Strømfjord shear zone and the Arfersiorfik quartz diorite in Arfersiorfik, the Nagssugtoqidian orogen, West Greenland. Geological Survey of Denmark and Greenland Bulletin 11, 145-161.

van Gool, J.A.M., Kriegsman, L.M., Marker, M. \& Nichols, G.T. 1999: Thrust stacking in inner Nordre Strømfjord area, West Greenland: significance for the tectonic evolution of the Palaeoproterozoic Nagssugtoqidian orogen. Precambrian Research 93, 71-86. 